\title{
Asymmetrical condition of the Bogor Basin (West Jawa, Indonesia) during the Middle Miocene to Pliocene based on taphonomic study of shellbed and its sequence architecture
}

\author{
Aswan ${ }^{1}$, Emmy Suparka ${ }^{1}$, Sonia Rijani ${ }^{2}$, Dessy Sundari ${ }^{2}$ and Emma Yan Patriani ${ }^{2}$ \\ Aswan, Emmy Suparka, Sonia Rijani, Dessy Sundari and Emma Yan Patriani (2008) Asymmetrical condi- \\ tion of the Bogor Basin (West Jawa, Indonesia) during the Middle-Miocene to Pliocene based on tapho- \\ nomic study of shellbed and its sequence architecture. Bull. Geol. Surv. Japan, vol.59 (7/8), 319-325, 4 figs.
}

\begin{abstract}
Examples of lithology, fossils and taphonomic features of shellbeds and intervening less-fossiliferous intervals are presented from two Middle Miocene to Pliocene successions of the Bogor Basin in West Jawa, Indonesia: the Nyalindung Formation in the Sukabumi area which was deposited in the western part of the basin and the Kaliwangu Formation in the Sumedang area, which is the eastern extent of sediments in the basin. As for Miocene to Pliocene $6^{\text {th }}$ order depositional sequences, the two successions contain a variety of shellbeds which are often associated with surfaces or intervals that are characterized by sedimentary condensation, omission or erosion (e.g., sequence boundaries, ravinement surfaces, downlap surfaces and condensed sections). Stratigraphic patterns in the shellbeds tend to be similar and repetitive within a basin with respect to position and age. For example, shellbeds formed in the context of toplap are common only in the Nyalindung Formation, and are characterized by thicker units of trangressive systems tracts (TST) and thin units of highstand systems tracts (HST). In contrast, sedimentary cycles from the eastern part of the basin in the Kaliwangu Formation can be recognized as formed under conditions of marine backlap and downlap, where the TST units are thin but the HST units are thicker. Such contrasting cycle architectures are interpreted to reflect an asymmetrical shelf depositional setting between the western and eastern edges of the Bogor Basin since Miocene to Pliocene time.
\end{abstract}

Keywords: taphonomic, shellbed, sequence architecture, bogor basin, Jawa, Indonesia, Nyalindung Formation, Kaliwangu Formation, Miocene, Pliocene

\section{Introduction}

The usefulness of shell concentrations as indicators of relative sea-level change, system tracts, and depositional sequences and their boundary surfaces, has been recognized for more than a decade (Abbott, 1997; Kondo et $a l ., 1998)$. The formation of depositional sequences implies drastic changes in the physical component of the shallow marine ecosystem. These changes can be recorded in the composition of faunistic assemblages and their taphonomic attributes (Kondo et al., 1998). In addition, distinctive types of shell beds occur at different positions within sedimentary cycles and provide evidence for the sequence stratigraphic interpretation of sedimentary successions.

One particular case is the Middle Miocene and Early Pliocene siliciclastic shallow marine sediments of the Nyalindung and Kaliwangu Formations exposed in West Jawa (Aswan, 2006; Aswan and Ozawa, 2006) (Fig. 1). This unit is characterized by the presence of numerous stratigraphic horizons with gastropods and pelecypods that offers an excellent opportunity for taphonomic study. These are important elements for identifying key sequence stratigraphic surfaces and systems tracts together with conventional analyses of sedimentary facies. Moreover, such contrasting cycle architectures could be used to interpret symmetrical and asymmetrical shelf palaeodepositional settings as an elements within a basin system (Kondo et al., 1998).

\section{Geologic setting}

Miocene through Pliocene marine sedimentary rocks in Jawa were chiefly preserved in offshore depocenters. However, while sedimentation still continues beneath modern sea level, some margins of the coastal basins have undergone gentle Plio-Pleistocene uplift, resulting in excellent coastal exposures of the Miocene to Pliocene siliciclastic successions. The Nyalindung and Kaliwangu Formations were deposited within the Bogor Basin

${ }^{1}$ Department of Geology, Faculty of Earth Sciences and Mineral Technology, Institute of Technology Bandung. Jl. Ganesha 10 Bandung, Indonesia (40132); E-mail: aswan_gl@gc.itb.ac.id

${ }^{2}$ Geological Survey Institute. Bandung, Indonesia 


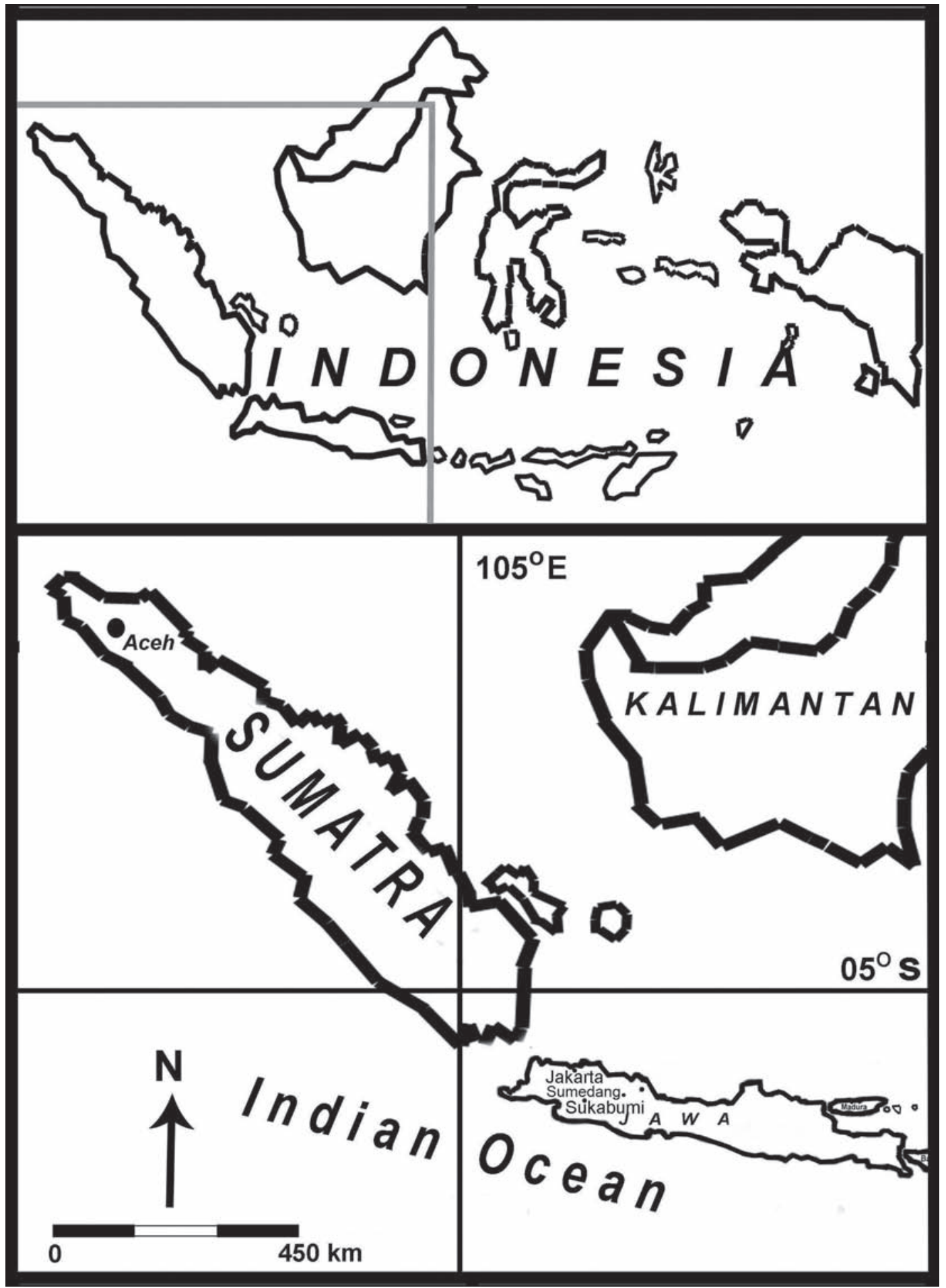

Fig 1 Map showing location of the study (Sukabumi and Sumedang)

(Martodjojo, 1984) (Fig. 2), which occupies a forearc position north of the modern convergence of the IndoAustralian Plate with Sundaland, separated from Banten Block to the west by the Tangerang High. Although poorly known, the Nyalindung and Kaliwangu Formations are one of the significant accumulations of mainly shallow marine Neogene strata exposed on land in West Jawa, and its outcrops represent a critical inter- val and a valuable reference section where environmental changes and glacio-eustasy evolution that affected this part of West Jawa during Miocene to Pliocene can be investigated.

\subsection{Nyalindung Formation}

The section was determined to be the lower part of this formation, where the lowest part of the section is identi- 
fied by the contact with the older Jampang Formation tuff and is bordered in the upper part by a normal fault (Sukamto, 1990). The precise geologic age of the formation is still debated due to the scarcity of planktonic foraminifers and calcareous nannoplankton. Nonetheless, it is estimated to be Middle Miocene or $\pm 12 \mathrm{Ma}$ BP on the basis of molluscs such as Vicarya verneuilli callosa MARTIN, Turritella angulata angulata MARTIN and Siphocypraea caputviperae MARTIN, as these taxa characterize the Preangerian Stage (Middle Miocene), a stage defined by Mollusca and proposed by Oostingh (1938-1939) who designated Citalahab River near the Nyalindung area, Sukabumi as the type-locality (Aswan, 1997; Aswan and Zaim, 1994). The reported Late/late Middle Miocene planktonic foraminifers identified by LEMIGAS (Indonesian Petroleum and Gas Department) indicate zone N.13 or \pm 12 Ma (Baumann, 1972; Baumann et al., 1973), with conversion from Neogene zonation to absolute age based on Saito (1999). A Middle Miocene age is also indicated by foraminifers such as Orbulina universa and Globigerinoides subquadratus (Aswan and Zaim, 1998a). In the present study we also estimate a Middle Miocene age, based on planktonic foraminifers; foraminifers such as Sphaeroidinellopsis seminulina, Gds. obliquus and O. universa are found in the lower part of this section in bed "A" (Dr. Tsunemasa Saito, Tokyo Research Institution, pers. comm.).

The formation was deposited in shallow marine to terrestrial environments, and grades laterally into the Bojonglopang Member of the Cimandiri Formation, which is partly covered by the Beser Formation (Sukamto, 1990). We infer therefore that the geological age of the Nyalindung Formation in this section is late Middle Miocene.

\subsection{Kaliwangu Formation}

The Cikandung-Cipedes section of the Kaliwangu Formation was determined to be the lower part of this formation, where the lowest part of the section is identified by a contact with the older Subang Formation. The later is characterized by muddy very fine sandstone, where the former is characterized by as alternation between mudstone and sandstone layers. The shellbeds of this unit mainly contain the gastropod Turritella angulata simplex in the lower part, whereas the pelecypod Placuna sp. dominates in the upper part. Foraminifera studied by Aswan and Zaim (1998b) suggest an Early-Pliocene age or N.18-N.19 according to Blow "s (1969) zonation. This age is based upon the first appearance of Pulleniatina obliqueloculata and last appearance of Globigerinoides obliquus.

\section{Materials and Methods}

Two stratigraphic sections each from the western and eastern parts of the Bogor Basin were measured and described (Figs. 3, 4). The sedimentologic study includes descriptions of lithology, sedimentary structures, and fossils. Based on these features, some taphonomic facies were recognized and grouped according to their vertical and lateral arrangement in several facies associations. Facies were initially identified and characterized in the field. Mollusc fossil concentrations were classified following Kondo et al. (1998) and Aswan

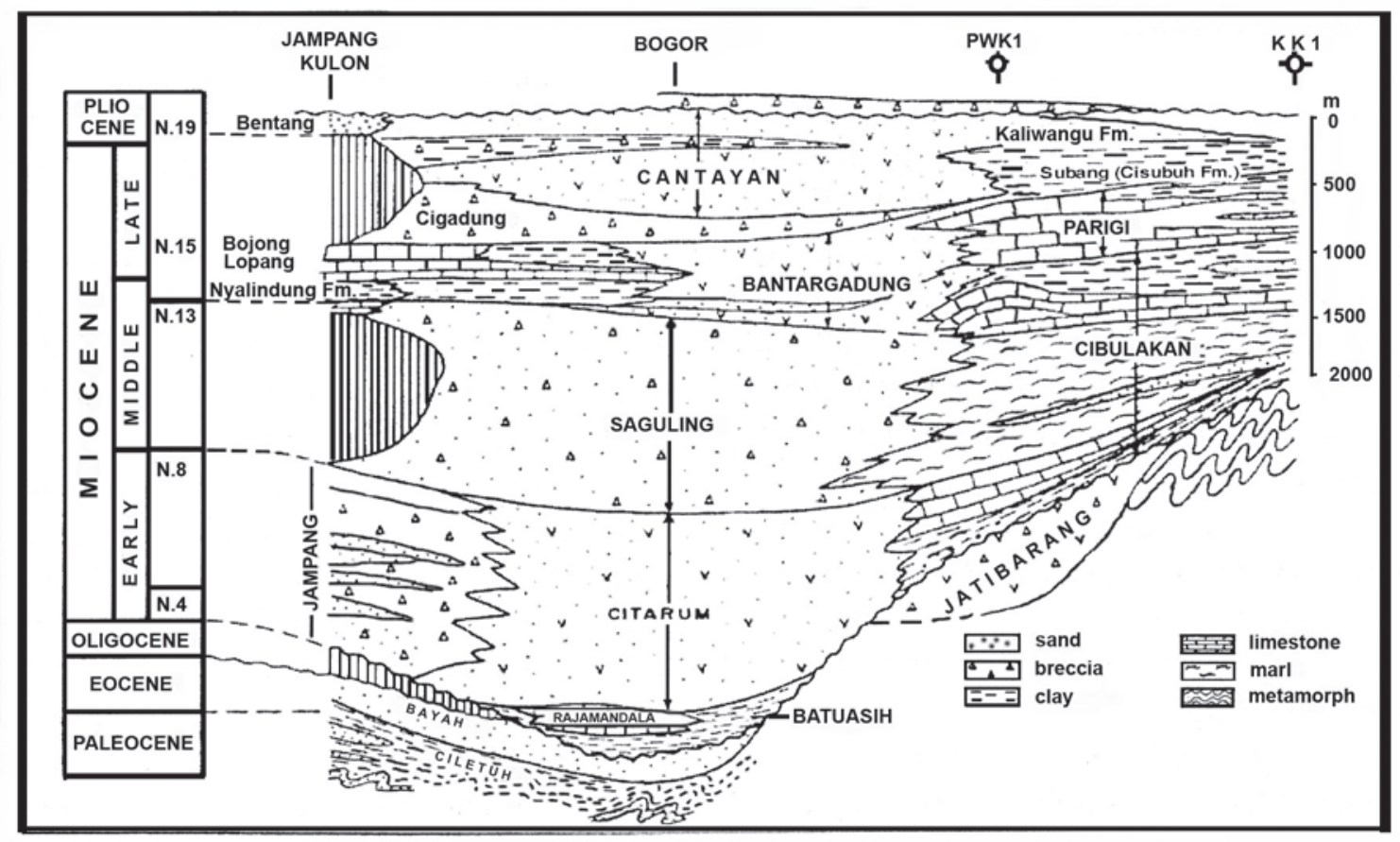

Fig. 2 West Jawa Regional Stratigraphy, Martodjojo (1984) 
(2006), considering their stratigraphy, inferred histories of accumulation, and position within the depositional sequence. Thus, several features were recorded, including stratigraphic (thickness, lateral extent, geometry, stratigraphic contacts, association with significant surfaces, and position within depositional sequence), sedimentologic (type of matrix, and associated physical and biogenic sedimentary structures), palaeoecological (taxonomic composition, life habits), and taphonomic (orientation, fragmentation, abrasion, disarticulation, encrustation, bioerosion) features.

Sequence stratigraphic analysis was used to infer changes in depositional conditions related to relative sea-level position, adopting the terminology proposed by Vail et al. (1991) and Van Wagoner et al. (1990). Its elements were determined based on the molluscs' taphonomic characteristics.

Taphonomic classification and each sequence stratigraphic element interpretation (Kondo et al., 1998 and Aswan, 2006) are:

1. Early TST: disarticulated and fragmented shells in bed, chaotic, strongly bioturbated, concretions, gravelly, plant fragments and thanatocoenosis suggestions

2. Late TST: articulated, life position shell concentrations, high density of epifaunal articulated shells, deeper environment shells present, starved sediments (thin layer?)

3. Early HST: juvenile and/ or individual articulated in life position shells, shell density and species diversity are rather low, shallower environment shells association suggestion, sometimes fragmented shells and carbonaceous stricts.

4. Late HST: multi-event concentration/ alternately, disarticulated shells, shallow environment shells association

\section{Physical stratigraphy}

The Middle Miocene siliciclastic fill of the western margin and the Early Pliocene fill of the eastern margin of the Bogor Basin (Nyalindung Formation) comprises a variable assemblage of marine to terrestrial strata.

The palaeontological and sequence stratigraphic analyses reported in this paper focus on the lower part of the Nyalindung Formation (Middle Miocene) and the relatively upper part of the Kaliwangu Formation (Early Pliocene). The limited exposure afforded by the modern abrasion platform and by faulting and folding preclude the reconstruction of a comparably well-defined, reliable physical stratigraphic architecture for the underlying formations that alternated with freshwater sediments.

\subsection{Depositional sequences in the Nyalindung Formation}

The lower part of the Nyalindung Formation consists of nine superposed, unconformity-bounded depositional sequences or cyclothems, numbered successively from Cycle 1 to Cycle 9 (Fig. 3), applying conventional sequence stratigraphic concepts developed for passive margin settings by researchers at Exxon Production

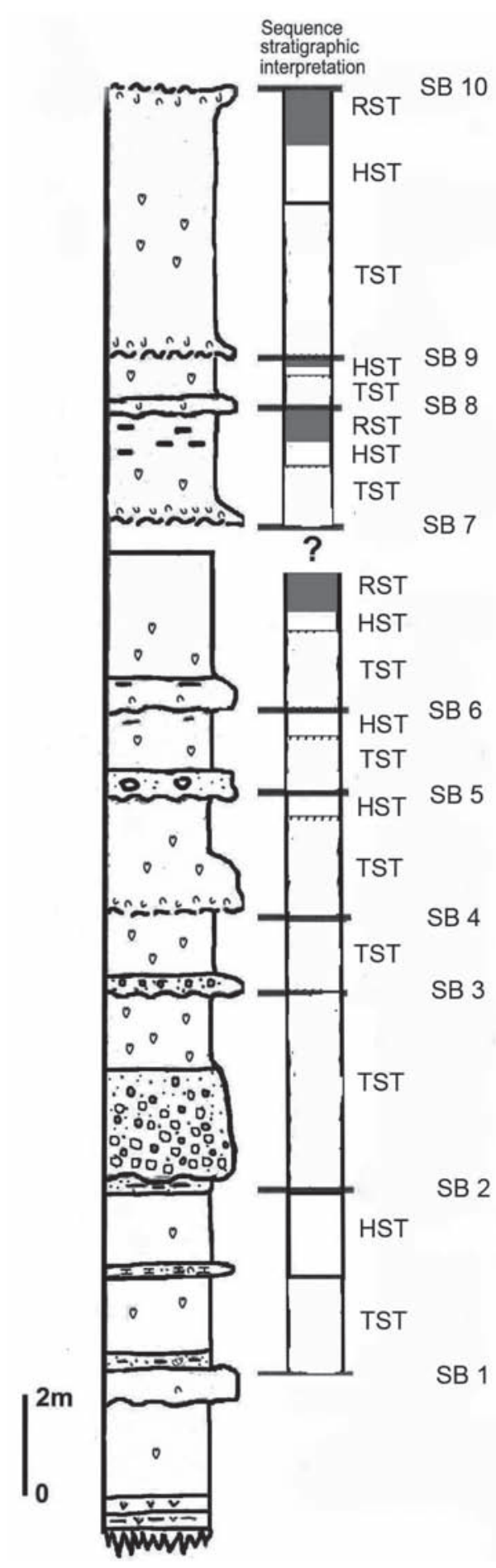

Fig. 3 Stratigraphic section of the Middle Miocene sedimentary successions exposed along the Cijarian River, Sukabumi, West Jawa, Indonesia. The nine depositional sequences identified are subdivided into component systems tracts. 
Research (e.g. Vail et al. (1991) and Van Wagoner et al. (1990)). This analysis requires identification of key stratal unconformities and palaeoenvironmental interpretations of the intervening sediments. Toward this end, our fieldwork has focused primarily on a detailed analysis of physical sedimentary characteristics. However, although many environments of deposition and surfaces were obvious on the basis of sedimentology alone, we have also taken advantage of the palaeoecological and taphonomic attributes of macrobenthic fossil mollusc assemblages as largely demonstrated by several works (Kondo et al. 1998; Cantalamessa et al., 2005; Parras and Casadío, 2005; Aswan, 2006); these kinds of data provide a wealth of valuable information on substrate consistency, water depth, shelf depositional processes, and sedimentary dynamics (e.g., sediment starvation versus bypassing versus erosion) at sequencebounding and intrasequence surfaces.

The total thickness of individual depositional sequences ranges from $\sim 0.5$ to $6 \mathrm{~m}$. An ideal sequence in the Nyalindung Formation is combination of a transgressive systems tract (TST), a highstand systems tract (HST) and regressive systems tract (RST). The HST is composed of shell-poor muddy sandstone whose lower contact marks the turn around from transgressive to regressive strata. In average for each sequence, TST deposits are thicker than HST deposits.

\subsection{Depositional sequences in the Kaliwangu Formation}

Bogor Basin eastern edge lithologic unit of Kaliwangu Formation consists of sixteen cyclothems, numbered respectively from Cycle 1 to Cycle 16 (Figure 4 ). This analysis requires identification of key stratal unconformities and palaeoenvironmental interpretations of the intervening sediments based on mollusc taphonomic studies. For this rock formation, although many environments of deposition and surfaces were clear on the basis of sedimentology, we have also taken advantage of the taphonomic characteristics, these kinds of data provide a wealth of valuable information on substrate consistency, and sedimentary dynamics (such as sediment starvation versus bypassing versus erosion) at sequence-bounding and intrasequence surfaces.

The total thickness of individual sequences in the Kaliwangu Formation range from $\sim 0.5$ to $5 \mathrm{~m}$. An ideal sequence in this formation is a combination of an early transgressive systems tract (TST), a late TST, an early highstand systems tract (HST) and a late HST phase.

The whole stratigraphic section indicates that for nearly all sequences, the HST units are thicker than the TST units, in contrast to characteristic Nyalindung Formation sequence stratigraphic elements .

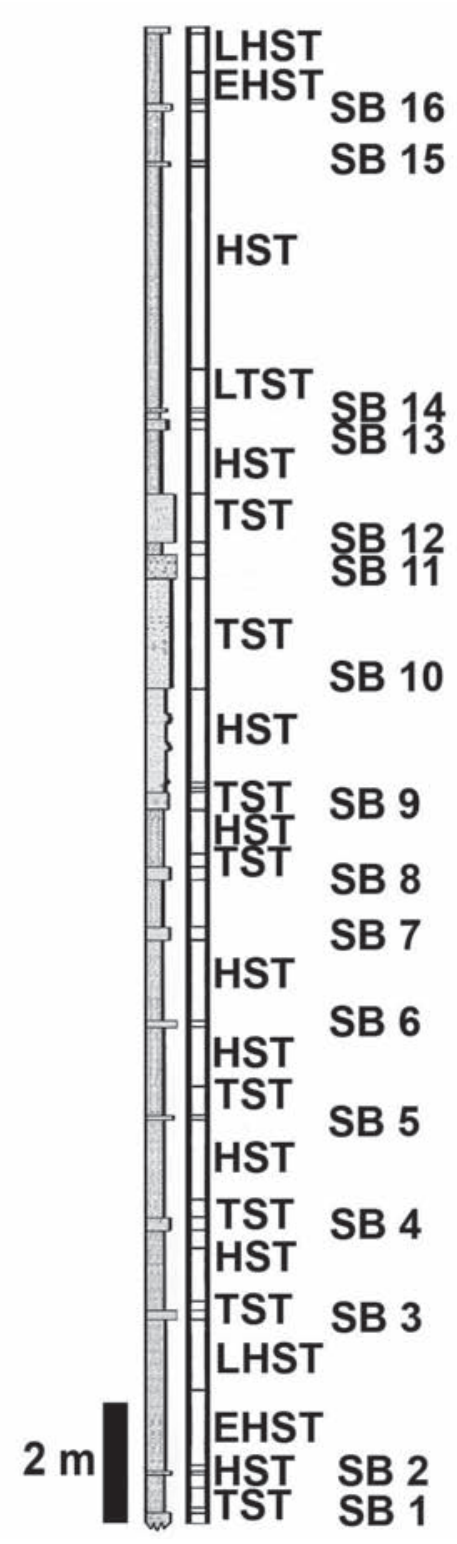

Fig. 4 Stratigraphic section of the Pliocene sedimentary successions exposed in the Cikandung and Cipedes River, Sumedang, West Jawa, Indonesia. The sixteen depositional sequences identified are subdivided into component systems tracts.

\section{Discussion and Conclusions}

The stratigraphic patterns of shellbed type in each mollusc assemblage in the Middle Miocene to Pliocene strata in the Bogor Basin tend to be similar and repetitive within a basin with respect to positions and ages. For example, shellbeds formed in the context of toplap are common only in the Nyalindung Formation, which is characterized by thicker units of trangressive systems tracts (TST) and thin units of highstand systems tracts (HST). In contrast, sedimentary cycles from the eastern part of the basin of the Kaliwangu Formation can be recognized as having formed under conditions of marine 
backlap and downlap, in which the TST units are thin but the HST units are thicker. Such contrasting cycle architectures are interpreted to reflect asymmetrical shelf depositional settings between the western and eastern edges of the Bogor Basin since the Miocene or Pliocene.

Acknowledgements: I wish to express my thanks to Professor Yahdi Zaim from the Dept. of Geology, Faculty of Earth Science and Mineral Technology, and to Professor Tomowo Ozawa of the Dept. of Earth and Planetary Sciences, Graduate School of Environmental Study, Nagoya University, Nagoya, Japan, for their encouragement throughout the present study. My thanks are also extended to Dr. Eddy A. Subroto, Ir. Lambok M. Hutasoit, Ph.D., Dr. Irwan Meilano, Dr. Tomoyuki Nakano, who helped with the Congress and provided literature that improved this paper.

\section{References}

Abbott, S. T. (1997) Mid-cycle condensed shellbeds from mid-Pleistocene cyclothems, New Zealand: implications for sequence architecture. Sedimentol., 44, 805-824.

Aswan (1997) Biometrical method using for Turritella molluscan fossil evolution analysis from several places in Jawa and its biostratigraphical significance. Master Thesis, Institut Teknologi Bandung. Bandung, Indonesia (in Indonesian with English abstract).

Aswan (2006) Taphonomic significance and sequence stratigraphy of the lower part of Nyalindung Formation (Middle Miocene), Sukabumi. Bull. Dep. Geol. Instit. Technol. Bandung, 38, 131-144.

Aswan and Ozawa, T. (2006) Milankovitch 41.000-year cycles in lithofacies and molluscan content in the tropical Middle Miocene Nyalindung Formation, Jawa, Indonesia. Palaeogeogr. Palaeoclimatol. Palaeoecol., 235, 382-405.

Aswan and Zaim, Y. (1994) Quantitative analysis of Turritella bantamensis from Bojong Formation, Pandeglang, West Jawa. Bull. Dep. Geol. Instit. Technol. Bandung, 24, 9-26 (in Indonesian).

Aswan and Zaim, Y. (1998a) Palaecological effect to the evolution of molluscan fossils from Nyalindung Formation, Sukabumi, West Jawa. Laporan Penelitian Lembaga Penelitian ITB, Institut Teknologi Bandung, Indonesia, no. 18622097 (in Indonesian with English abstract).

Aswan and Zaim, Y. (1998b) Palaeoecological effect evidence on Turritella angulata simplex evolution of Pliocene Kaliwangu Formation, Sumedang area, West Jawa. Bull. Dep. Geol. Instit. Technol. Bandung, 30, 1-11. (in Indonesian).

Baumann, P. (1972) Summary of the stratigraphical results obtained during the Southwest Jawa field compaign of Lemigas. Lemigas Report, Jakarta, Indonesia, no. EP-0164.

Baumann, P., Genevraye, P. de, Samuel, L. Mudjito and Sajekti, S. (1973) Contribution to the geological knowledge of Southwest Jawa. Proc. Second Ann. Convent. Indonesian Petrol. Assoc., Jakarta, Indonesia, 105-108.

Blow, W. H. (1969) Late Middle Eocene to Recent planktonic foraminiferal biostratigraphy. In Brönnimann, P. and Renz, H.R., eds., Proceedings of First International Conference of Planktonic Microfossils, Geneva, 1967, 1, 199- 422.

Cantalamessa, G., Di Celma, C. and Ragaini, L. (2005) Sequence stratigraphy of the Punta Ballena Member of the Jama Formation (Early Pleistocene, Ecuador): insights from integrated sedimentologic, taphonomic and palaeoecologic analysis of molluscan shell concentrations. Palaeogeogr. Palaeoclimatol. Palaeoecol., 216, 1-25.

Kondo, Y., Abbott, S. T., Kitamura, A., Kamp, P. J. J., Naish, T. R., Kamataki, T. and Saul, G. S. (1998) The relationship between shellbed type and sequence architecture: examples from Japan and New Zealand. Sediment. Geol., 122, 109-127.

Martodjojo, S. (1984) Evolution of Bogor Basin, West Jawa. ITB Doctor Dissertation, 396p. (unpublished).

Oostingh, C. H. (1938-1939) Die Mollusken des Pliocaens von Sud-Bantam in Java. De Ingenieur In Nederlandsh Indie Nummer 2, Palaontologe beim 'Dienst vanden Mijnbow', Bandung.

Parras, A. and Casadio, S. (2005) Taphonomy and sequence stratigraphic significance of oyster-dominated concentrations from the San Julián Formation, Oligocene of Patagonia, Argentina. Palaeogeogr. Palaeoclimatol. Palaeoecol., 217, 47-66.

Saito T. (1999) Revision of Cenozoic magnetostratigraphy and the calibration of planktonic microfossil biostratigraphy of Japan against this new time scale. Jour. Japan. Assoc.Petro-l. Technol., 64, 1-15.

Sukamto, R. (1990) Geology of the Jampang and Balekambang Sheet area, West Jawa. Department of Mines and Energy - Directorate General of Geology and Mineral Resources - Geological Research and Development Centre, Bandung.

Vail, P. R., Audemard, F., Bowman, S. A., Eisner, P. N. and Perez-Curz, C. (1991) The stratigraphic signatures of tectonics, eustacy and sediemtology - an overview. In Einsele, G., Ricken, W. and Seilacher, A. eds., Cycles and Events in Stratigraphy, Springer, Berlin, 617-659.

Van Wagoner, J. C., Mitchum, R. M., Campion, K. M. and Rahmanian, V. D. (1990) Siliciclastic sequence stratigraphy in well logs, cores, and outcrops: concepts for high-resolution correlation of time and 
facies. A.A.P.G. Methods for Exploration Series, Tulsa 7, 55p.
Received July, 15, 2008

Accepted September, 16, 2008

(The Indonesian references are cited as their English titles were given in Indonesian journals.)

\title{
貝殼層のタフォノミーとシークエンス層序に基づいて復元したボゴール堆積盆 (インドネシアジャワ島西部) の中期中新世から鮮新世の非対称な堆積環境
}

\author{
アスワン・エミー スパルカ・ソニア リジャニ・ \\ デシイ スンダリ・エマ ヤン パットリアニ
}

要 旨

インドネシア西ジャワのボゴール堆積盆の中期中新統から鮮新統にいたる二つの地域に, 様々な貝㪍層のタフォノ ミーの様相や貧化石帯の挟みなどが存在する。この二つとは堆積盆西部に堆積したサカブミ地域のニャリンダン層, お よび堆積盆東方に発達するカリワング層である。この中新世から鮮新世における 6 オーダーの堆積シークエンス体には, コンデンセイション層や無堆積と侵食などの堆積面などを伴って様々な様式の貝款層を含んでいる。これらの堆積体に はシークエンス境界や, ラビンメント面, ダウンラップ面, それにコンデンスセクションなどが認められる。ここでは, ある堆積様式の貝殼層の層序的パターンが堆積盆の位置や年代に応じて類似したり繰り返している。例えば，トップ ラップに関与している貝殼層はニャリンダン層中にのみ認められ，これは海進期堆積体（TST）の厚い堆積ユニットと 高海水準期堆積体（HST）の薄い堆積ユニットを特徵づけている. 対照的に堆積盆の東方にあるカリワング層の堆積サ イクルはバックラップとダゥンラップの様式で形成され，これはTST が薄く, HST が厚い特徴を有する。このような東 西での対照的な堆積サイクルの構築構造は, 中新世から鮮新世にかけてのボゴール堆積盆での非対称性の陸棚堆積の形 成場を反映したものと解釈される。 